DOI

\author{
${ }^{\odot}$ А. Ю. Пекарь \\ ДВНЗ «Ужгородсъкий національний університет»
}

\title{
СТАН НОВОНАРОДЖЕНИХ ТА ПЕРЕБІГ РАННЬОГО НЕОНАТАЛЬНОГО ПЕРІОДУ В ДІТЕЙ ВІД МАТЕРІВ ІЗ ВІРУСНОЮ ЕПШТЕЙНА-БАРР ІНФЕКЦІЕЮ
}

СТАН НОВОНАРОДЖЕНИХ ТА ПЕРЕБІГ РАННЬОГО НЕОНАТАЛЬНОГО ПЕРІОДУ В ДІТЕЙ ВІД МАТЕРІВ ІЗ ВІРУСНОЮ ЕПШТЕЙНА-БАРР ІНФЕКЦІЄЮ. Проаналізований стан новонароджених від матерів із реактивацією вірусної Епштейна-Барр інфекції характеризується вірогідно високим рівнем перинатальних ускладнень: ассріксії різного ступеня тяжкості (47,8 \%), синдрому затримки розвитку плода, асиметричної фрорми (34,8 \%), постгіпоксичної енцефалопатії (23,2 \%), гіпербілірубінемії $(21,7 \%)$, геморагічного синдрому $(13,0 \%)$ та реалізації інтраамніального інфрікування $(8,7 \%)$. Вищенаведене вказує на високу частоту захворюваності дітей у ранній неонатальний період (68,2 \%), що, безсумнівно, зумовлює важливу медикосоціальну проблему.

СОСТОЯНИЕ НОВОРОЖДЕННЫХ И ТЕЧЕНИЕ РАННЕГО НЕОНАТАЛЬНОГО ПЕРИОДА У ДЕТЕЙ ОТ МАТЕРЕЙ С ВИРУСНОЙ ЭПШТЕЙНА-БАРР ИНФЕКЦИЕЙ. ПроаналИзированное состояние новорожденНЫХ от матерей с реактивацией вирусной Эпштейна-Барр инфекции характеризуется достоверно высоким уровнем перинатальных осложнений: асфриксии различной степени тяжести (47,8\%), синдрома задержки развития плода, асимметричной формы $(34,8 \%)$, постгипоксической энцесралопатии (23,2 \%), гипербилирубинемии (21,7\%), геморрагического синдрома $(13,0 \%)$, реализации интраамниального инфицирования (8,7 \%). Вишесказанное указывает на высокую частоту заболеваемости детей в раннем неонатальном периоде (68,2 \%), что, несомненно, обусловливает важную медико-социальную проблему.

STATE OF NEWBORNS AND THE COURSE OF EARLY NEONATAL PERIOD IN CHILDREN FROM MOTHERS WITH EPSTEIN-BARR VIRUS INFECTION. The state of newborns from mothers with viral reactivation of Epstein-Barr virus infection is characterized by a fairly high level of perinatal complications of varying severity asphyxia (47.8 \%), fetal growth retardation, asymmetric form (34.8\%), posthypoxic encephalopathy (23.2\%), hyperbilirubinemia (21.7\%), hemorrhagic syndrome (13.0 \%), implementing intra-amniotic infection $(8.7 \%)$. The foregoing indicates a high rate of morbidity in children in the early neonatal period $(68.2 \%)$, which undoubtedly makes an important medical and social problem.

Ключові слова: вірус Епштейна-Барр, вагітні, плід, затримка розвитку плода, новонароджені.

Ключевые слова: вирус Эпштейна-Барр, беременные, плод, задержка развития плода, новорожденные.

Key words: Epstein-Barr virus, pregnant, fetus, growth retardation, newborn.

ВСТУП. Протягом останніх десятиліть спостерігається зростання захворюваності, спричиненої герпесвірусами, особливо вірусом Епштейна-Барр (ВЕБ) [8]. Цей вірус займає важливе місце в структурі інсекційних уражень, $€$ достатньо поширеним у людській популяції, ним інфіковано майже 90-100 \% дорослого населення і від 50 до $80 \%$ - дитячого $[1,3,5]$.

В 1964 році ВЕБ уперше виявили під електронним мікроскопом у клітинах культури лімсоми Беркітта вчені M. A. Epstein, B. G. Achong i Y. M. Barr. У 1968 році була показана етіологічна роль ВЕБ як етіологічного чинника при інорекційному мононуклеозі. У 1970 році ДНК ВЕБ виявили в тканинах хворих з назофарингеальною карциномою [4, 7]. У 1980-х роках була виявлена асоціація ВЕБ з неходжкінською лімфомою і волосатою лейкоплакією язика у хворих з ВІЛінфекцією. 3 того часу ДНК ВЕБ виявляли в тканинах при різних онкологічних захворюваннях, включаючи Т-клітинні лімфоми і хворобу Ходжкіна. Таким чином, було доведено, що ВЕБ може призводити до неопластичної трансформації клітин людини $[6,7]$. Накопичені за минулий період знання свідчать про колосальну роль ВЕБ в інфекційній, онкологічній та імунологічній патології людини. На даний час доведено роль ВЕБ у розвитку ряду злоякісних пухлин, аутоімунних захворювань, синдрому хронічної втоми (СХВ) і патології нервової системи (енцесраліти, менінгіти, мієліти, полірадикулонейропатії) [1, 5-7].
Шляхи передачі ВЕБ: повітряно-краплинний, контактнопобутовий, парентеральний, статевий $[3,5,8]$. Описані випадки вертикальної трансмісії ВЕБ від матері до плода 3 розвитком внутрішньоутробної ВЕБ-інсрекції $[1,2,7]$. Активна ВЕБ-інфекція під час вагітності призводить до ранньої загибелі ембріона, передчасних пологів або народження дитини з вадами розвитку - уродженою катарактою, крипторхізмом, змінами кісток за типом «стебла селери». При інтранатальному інорікуванні можливе захворювання дитини через короткий проміжок часу після народження, нерідко у вигляді енцефраліту [5-7].

Внутрішньоутробна ВЕБ-інфекція займає значне місце, складаючи близько 50 \%, може викликати різні ураження плода та новонародженого: ураження нервової системи (28\%), органів зору (7\%), рецидивний хроніосепсис (13\%), гепатопатію і синдром дихальних розладів [1, 2, 5-7].

Метою дослідження $є$ вивчення перинатальних ускладнень та особливостей перебігу раннього неонатального періоду в дітей, які народилися від матерів із ВЕБ-інфекцією.

МАТЕРІАЛИ ТА МЕТОДИ. У період 2014-2015 років проведено обстеження 250 вагітних, розроджених в Ужгородському міському пологовому будинку. Всі жінки пройшли загальноклінічне обстеження згідно з наказом MO3 України № 417 та комплексне дослідження на ВЕБ. 
Визначали антитіла Ig M i lg G до капсидного, нуклеарного та ранніх антигенів ВЕБ (VCA, EBNA, EA VEB), авідність антитіл Ig G до капсидного антигену ВEБ (VCAVEB) за допомогою імуносрерментного аналізу (IФА) та ДНК BEБ (DNAVEB) у сироватці крові вагітних за допомогою полімеразно-ланцюгової реакції (ПЛР). Визначали сироваткові маркери на базі клінічної лабораторії Закарпатського обласного центру профілактики та боротьби зі СНІДом із використаням тест-систем: «Вектор-Бест» (Новосибірськ, РФ), «Euroimmun AG» (Німеччина), «Bio-Rad» (США), «АмплиСенс» (РФ).

Вивчення стану специфічного імунітету виявило наявність антитіл до ВЕБ в усіх вагітних, тобто рівень інфрікування серед обстежених становив 100 \%. Кожна третя жінка переносила активну ВЕБ-інфекцію: 5 (2,0 \%) вагітних - гостру первинну, 71 (28,4\%) вагітна - реактивацію хронічної персистувальної інфрекції. У 35 (14,0 \%) жінок мала місце латентна ВЕБ-інфекція. Більше ніж у половини обстежених - 137 (54,8 \%) спостерігалася хронічна неактивна ВЕБ-інфекція. У перифреричній крові 2 (0,8 \%) вагітних виявлено ДНК ВЕБ.

Для досягнення поставленої мети проведено клінікостатистичний порівняльний аналіз перинатальних ускладнень та перебігу раннього неонатального періоду в 104 живих дітей, народжених від матерів із ВЕБінфекцією. Основну групу склали 69 новонароджених від матерів із реактивацією ВЕБ-інфекції під час вагітності, контрольну - 35 новонароджених від жінок із латентною ВЕБ-інфекцією, без акушерської та соматичної патології. У дослідження навмисно не включали дітей, народжених від жінок із гострою первинною та хронічною неактивною ВЕБ-інфеекцією, мертвонароджених.

Результати досліджень оброблено за допомогою пакета прикладних програм «Statistica». Для оцінки достовірності (p) різниці між групами показників використовували t-критерій Стьюдента. У науковій роботі був прийнятий рівень достовірності $p<0,05$.

РЕЗУЛЬТАТИ ДОСЛІДЖЕННЯ ТА ЇХ ОБГОВОРЕННЯ. Всього у жінок із реактивацією ВЕБ-інфекції та латентною
ВЕБ-інфекцією народилось 106 (100 \%) дітей, із них: 104 $(98,1 \%)$ - живих; 2 (1,9 \%) - мертвих, зокрема в обох випадках мертвонародження мала місце антенатальна загибель плода на 36 та 38-39 тижнях гестації відповідно. У жінок із реактивацією ВЕБ-інфекції були недоношені 34 (49,3 \%) новонароджені. Гестаційний вік досліджуваних новонароджених становив 28-42 тижні.

В основній групі народилося 34 (49,3 \%) хлопчики та 35 (50,7 \%) дівчаток, у контрольній - 20 (57,1 \%) та 15 (42,9 \%) відповідно. Маса тіла новонароджених основної групи коливалася в межах 1100-4050 г, контрольної - 2650-4400 г. Середня маса тіла новонароджених основної групи - $(2433,1 \pm 871,8)$ г, у групі контролю - $(3585,7 \pm 814,3)$ г $(p<0,05)$. Антропометрична характеристика новонароджених наведена у таблиці 1.

Як видно 3 таблиці 1, у новонароджених основної групи спостерігалися вірогідно нижчі значення за всіма антропометричними показниками $(p<0,05)$.

За даними таблиці 2, серед дітей основної групи практично здоровими народилися 36 немовлят, що становило 52,2 \% випадків, порівняно з контрольною групою, де дітки в задовільному стані народилися в 91,4 \% випадків $(p<0,05)$.

Аналіз перинатальних ускладнень в основній групі показав вірогідно високу частоту асфріксії різного ступеня тяжкості - 47,8 \% випадків, у контрольній групі - 5,7\% $(p<0,05)$. Частота синдрому затримки розвитку плода, асиметрична фрорма в цих новонароджених у основній групі становила 34,8 \%, у контрольній - 2,8 \% (p<0,05). Макроскопічні ознаки внутрішньоутробного інфрікування мали місце в 12 випадках у дітей основної групи, що склало, відповідно, 17,4 \%.

У неонатальний період серед новонароджених основної групи спостерігалася вірогідно вища частота постгіпоксичної енцесралопатії (23,2 \%), гіпербілірубінемії $(21,7 \%)$, геморагічного синдрому $(13,0 \%)$ та реалізації інтраамніального інсрікування (8,7 \%) (табл. 3).

В основній групі захворюваність новонароджених у ранній неонатальний період становила 68,2 \% випадків, у

Таблиця 1. Антропометрична характеристика новонароджених

\begin{tabular}{|l|c|c|}
\hline \multicolumn{2}{|c|}{ Показник } & \multicolumn{2}{c|}{ Група дітей } \\
\cline { 2 - 3 } & контрольна $(\mathrm{n}=35)$ & основна $(\mathrm{n}=69)$ \\
\hline Маса тіла, г & $3585,7 \pm 814,3$ & $2433,1 \pm 871,8^{*}$ \\
\hline Довжина тіла, см & $53,3 \pm 4,3$ & $49,0 \pm 5,2^{\star}$ \\
\hline Окружність голови (ОГ), см & $33,8 \pm 2,8$ & $30,3 \pm 2,4^{\star}$ \\
\hline Окружність грудної клітки (ОГК), см & $34,1 \pm 2,9$ & $29,9 \pm 4,5^{\star}$ \\
\hline
\end{tabular}

Примітка. Тут і в наступних таблицях: * - різниця достовірна порівняно з показниками КГ (р<0,05).

Таблиця 2. Стан новонароджених, абс.ч. (\%)

\begin{tabular}{|l|c|c||}
\hline \multirow{2}{*}{\multicolumn{1}{|c|}{ Показник }} & \multicolumn{2}{c||}{ Група дітей } \\
\cline { 2 - 3 } & контрольна $(\mathrm{n}=35)$ & $36(52,2)^{\star}$ \\
\hline Задовільний & $32(91,4)$ & $25(36,2)^{\star}$ \\
\hline Ассріксія легкого ступеня & $2(5,7)$ & $5(7,3)$ \\
\hline Ассріксія середнього ступеня & - & $3(4,3)$ \\
\hline Тяжка ассріксія & - & $24(34,8)^{\star}$ \\
\hline Синдром затримки розвитку плода & $1(2,8)$ & $12(17,4)$ \\
\hline Макроскопічні ознаки внутрішньоутробного інфікування & - & \multicolumn{1}{c|}{ основа } \\
\hline
\end{tabular}


Таблиця 3. Перебіг раннього неонатального періоду, абс.ч. ( \%)

\begin{tabular}{|l|c|c|}
\hline \multirow{2}{*}{\multicolumn{1}{|c|}{ Показник }} & \multicolumn{2}{c|}{ Група дітей } \\
\cline { 2 - 3 } & контрольна $(\mathrm{n}=35)$ & основна $(\mathrm{n}=69)$ \\
\hline Постгіпоксична енцесралопатія & $2(5,7)$ & $6(8,2)$ \\
\hline Реалізація внутрішньоутробного інфрікування & - & $10(14,5)$ \\
\hline Геморагічний синдром & - & $15(21,7)^{\star}$ \\
\hline Гіпербілірубінемія & $1(2,8)$ & $47(68,2)^{\star}$ \\
\hline Всього & $3(8,6)$ & \\
\hline
\end{tabular}

контрольній групі вона склала 8,6 \% (p<0,05). Сумарні перинатальні втрати у вагітних із реактивацією ВЕБ-інсрекції (n=71) становили 28,2\% (два випадки антенатальної загибелі плода). У групі контролю перинатальних втрат не було.

ВИСнОВкИ. Проведений аналіз свідчить про те, що немовлята основної групи народилися 3 більш вірогідно нижчими антропометричними показниками та нижчою оцінкою за шкалою Апгар порівняно 3 немовлятами контрольної групи. Захворюваність дітей у ранній неонатальний період, народжених жінками з реактивацією ВЕБ-інфрекції під час вагітності, була вірогідно вищою порівняно $з$ дітьми, яких народили жінки з латентною ВЕБ-інфекцією.

ПЕРСПЕКТИВИ ПОДАЛЬШИХ ДОСЛІДЖЕНЬ. Проаналізовані результати вказують на високу частоту перинатальних ускладнень у дітей від матерів із ВЕБінсеекцією, що, безсумнівно, пов'язано з функціональним станом системи «мати-плацента-плід». Це єпідставоюдля більш глибокого вивчення особливостей фрункціонального стану фретоплацентарного комплексу.

\section{СПИСОК ЛІТЕРАТУРИ}

1. Беременность и инфекция, вызванная вирусом Епштейна-Барр / Т. Н. Савченко, В. А. Алешкин, М. И. Агаева [и др.] // Здоровье женщины. - 2015. - № 1. - С. 17-21.

2. Эпштейна-Барр вирусная инфекция в перинатологии / В. Б. Котлова, С. П. Кокорева, Е. В. Аралова [и др.] // Здоровье и образование в XXI веке. - 2013. - Т. 15, № 8 . - С. 1-7.

3. Інфекційний мононуклеоз у дітей: клініко-імунологічна характеристика / Г. О. Леженко, О.В.Усачова, Є. А. Сіліна [та ін.] // Актуальная иноектология. - 2013. - № 1 (1). C. $56-60$.

4. Лешак В. І. Особливості назофраренгеальної карциноми, асоційованої із Епштейна-Барр вірусом / В. І. Лешак, В. І. Попович // Журнал вушних, носових і горлових хвороб. -2015 . - № 4. - C. 16-21.
5. Казмирчук В. Е. Диагностика и лечение инсекции, вызванной Эпштейна-Барр вирусом (вирусом герпеса человека 4 типа) / В. Е. Казмирчук, Д. В. Мальцев // Клінічна імунологія. Алергологія. Інсректологія. - 2011. - № 4 (43). - C. $69-75$.

6. Клінічні срорми хронічної Епштейна-Барр вірусної інфекції: питання сучасної діагностики та лікування / О.К. Дуда, Р. О. Колесник, М. В. Окружнов [та ін.] // Актуальная инсектология. - 2015. - № 1 (6). - С. 35-40.

7. Крамарев С. А. Эпштейна-Барр вирусная инфекция у детей / С. А. Крамарев, О. В. Выговская // Актуальная инфектология. - 2013. - № 1 (1). - С. 73-78.

8. Покровська Т. В. Хронічна Епштейна-Барр вірусна інсрекція - актуальні питання / Т.В.Покровська // Інфекційні хвороби. - 2014. - № 2. - С. 70-74. 